\title{
Polysorbate 80 and Helicobacter pylori: a microbiological and ultrastructural study
}

\author{
Natale Figura ${ }^{1 *}$, Roberto Marcolongo ${ }^{2}$, Giovanni Cavallo ${ }^{3}$, Annalisa Santucci $^{4}$, Giulia Collodel ${ }^{5}$, \\ Adriano Spreafico ${ }^{6}$ and Elena Moretti ${ }^{5}$
}

\begin{abstract}
Background: The frequent occurrence of chemoresistant strains reduces the chances of eradication of $\mathrm{H}$. pylori infection and prompted the investigation of non-antibiotic substances active against this organism. Some surfactants enhance the effectiveness of antibiotics for their permeabilizing properties towards bacteria. We examined the antimicrobial activity to $\mathrm{H}$. pylori of the surfactant polysorbate 80 , used alone and in association with amoxicillin, clarithromycin, metronidazole, levofloxacin and tetracycline. We also aimed to study the ultrastructural alterations caused upon $H$. pylori by polysorbate 80 , alone and in combination with antibiotics. Twenty-two H. pylori strains were tested using the broth dilution method. After incubation, broth from each dilution was subcultured onto agar enriched with foetal bovine serum to determine the minimum bactericidal concentration (MBC). Synergistic effect of polysorbate 80 with antibiotics was investigated by the broth dilution and disc diffusion techniques. Ultrastructural alterations of organisms treated with polysorbate 80 , alone and in association with antibiotics were analyzed by transmission electron microscopy.

Results: MBCs of polysorbate 80 ranged from $2.6(1.1) \mu \mathrm{g} / \mathrm{ml}$ to $32(0) \mu \mathrm{g} / \mathrm{ml}$. Polysorbate 80 exerted a synergistic effect when associated with metronidazole and clarithromycin: polysorbate 80 and metronidazole MBCs decreased by $\geq 4$ fold; clarithromycin MBCs for two resistant strains decreased by 20 and 1000 times. The principal alteration caused by polysorbate 80 consisted in the detachment of the outer membrane of bacteria.
\end{abstract}

Conclusions: The bactericidal activity of polysorbate 80 and the synergistic effect of the association with metronidazole and clarithromycin could be useful in the treatment of $\mathrm{H}$. pylori infection.

Keywords: Bacteria, Antibiotics, Chemoresistances, Polysorbate 80, Transmission electron microscopy

\section{Background}

Helicobacter pylori is a microaerophilic gram-negative helical-shaped bacterium that infects approximately $30 \%$ of the population in developed countries and up to $90 \%$ of the population in developing countries [1,2].

The standard treatment of $H$. pylori infection, triple therapy, consists of two antibiotics and a proton pump inhibitor (PPI), or ranitidine bismuth citrate, administered for one or two weeks [3,4]. Amoxicillin, clarithromycin (or azithromycin), imidazoles (metronidazole or tinidazole), levofloxacin and tetracycline are the antibiotics used in the first and second line treatments. Options

\footnotetext{
*Correspondence: figura@unisi.it

'Department of Internal Medicine, University of Siena, Siena, Italy

Full list of author information is available at the end of the article
}

for third and subsequent line therapies include rifabutin and furazolidone-based regimes [5].

Recent protocols, such as the so-called sequential therapy, seem more successful than triple therapy; such treatment employs three antibiotics and a PPI and lasts for 10 days [6]. In 2011, Malfertheiner et al. [7] proposed a quadruple therapy (two antibiotics, tetracycline and metronidazole, PPI and bismuth) as a first line treatment because of the increasing prevalence of clarithromycin resistant strains.

Treatment failure is observed in $10 \%-23 \%$ of patients $[4,8]$ and is mainly due to loss of antibiotic efficacy; in particular, the worldwide $H$. pylori antibiotic resistance rates in 2010 were $17.2 \%$ for clarithromycin, $26.7 \%$ for metronidazole, $11.2 \%$ for amoxicillin, $16.2 \%$ for levofloxacin, $5.9 \%$ for tetracycline and $9.6 \%$ for multiple antibiotics [9]. This dramatic fall in the eradication rates [10]

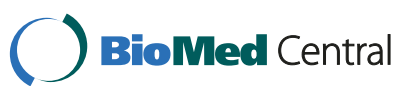


strongly indicates the need to improve current therapeutic strategies and to develop new drugs, such as nonantibiotic substances [11-13]. Vitor and Vale [14] reviewed the study of alternative therapies, mainly probiotics and phytomedicine, for H. pylori infection. Probiotics attenuate the side effects of antibiotics and improve their efficacy; some plant extracts possess antiH. pylori properties [14], but in this case, the active component should be identified, the mechanism of action and the potential toxicity for the patient explored, finally the possible resistance against these new phytotherapeutic agents addressed.

Among the numerous compounds with potential antibacterial properties, polysorbates, a class of substances derived from sorbitan, known with the commercial name of Tween ${ }^{\circledR}$, are particularly appealing. In particular, polysorbate 80 is a nonionic surfactant used as an emulsifier in food, for example ice cream (where it is employed in concentrations of up to $0.5 \%$ ). It is also used in bacterial broth cultures to prevent foam formation and as an excipient in numerous medications and vaccines against influenza to stabilize aqueous formulations. It is reputed to be a generally safe and well-tolerated compound.

These substances, in particular Tween 80, have been employed for their nature of surfactant to produce microemulsion systems with glycerol monolaurate as oil and organic acids as co-surfactant; such microemulsions caused a complete loss of viability of Staphylococcus aureus and Escherichia coli [15]. The potential antimicrobial activity of Tweens alone, however, was not explored. Other surfactants, such as dodecyl maltoside and octyl glucoside, enhanced the effectiveness of antibiotics used in the treatment of human pulmonary tuberculosis for their permeabilizing properties [16]. Finally, Huesca et al. [17] examined some substances, included Tween detergents, considered, in the past, efficacious treatments for peptic ulcer, and found that they were able to inhibit H. pylori receptor binding in vitro.
All these observations suggest that detergents could be useful in the treatment of $H$. pylori infection, although their potential antibacterial activity against H. pylori has not been examined yet. The aims of this study were: a) to determine the antimicrobial activity against $H$. pylori of polysorbate 80 and antibiotics most commonly used to eradicate $H$. pylori infection: amoxicillin, clarithromycin, metronidazole, levofloxacin and tetracycline; b) to find out whether the association of polysorbate 80 with antibiotics could increase their activity; c) finally, to investigate on the possible ultrastructural morphological alterations exerted upon H. pylori by polysorbate 80 (alone and in associations with clarithromycin and metronidazole), which could help explaining its mechanism of action.

\section{Results}

\section{Characteristics of strains tested}

The 22 strains tested include the different genotypes of H. pylori (i.e. cagA-positive or -negative) and different source of isolation, i.e. from patients with chronic gastritis only (CGO), duodenal ulcer (DU) and gastric carcinoma $(\mathrm{GC})$. Fifteen strains were primary strains (that is isolated from patients naïve for eradication treatment), seven strains, isolated from patients unsuccessfully treated with the triple therapy, were named as secondary. The strain characteristics are reported in Table 1. Out of the 22 strains tested, six strains were isolated from patients with GC, three strains from cases of DU and the others from patients with CGO. Sixteen strains possessed the cagA gene; strain $328 \mathrm{Km}$ was a cagA-negative isogenic mutant of the wild cagA-positive isolate 328 (Table 1).

\section{Determination of the chemosusceptibility of $H$. pylori strains to polysorbate 80 and antibiotics}

The results of the chemosusceptibility tests are expressed in $\mu \mathrm{g} / \mathrm{mL}$ and are reported in Table 2 as mean and standard deviation in parentheses. MBCs of polysorbate 80 ranged from 2.6 (1.1) to 32 (0) (Table 2); the $\mathrm{MBC}_{50}$ (the

Table 1 Characteristics of $\boldsymbol{H}$. pylori strains tested

\begin{tabular}{|c|c|c|c|c|c|c|c|c|c|c|c|c|c|c|c|c|c|c|c|c|c|c|}
\hline \multirow[t]{2}{*}{ Parameter } & \multicolumn{22}{|c|}{ Helicobacter pylori strains } \\
\hline & $\begin{array}{l}\text { CCUG } \\
17874\end{array}$ & G50 & G21 & $4 \mathrm{~Kb}$ & DiSim & $10 \mathrm{~K}$ & 328 & $\begin{array}{c}328 \\
\mathrm{Km}^{*}\end{array}$ & $\begin{array}{c}\mathrm{M} / \mathrm{C}- \\
\mathrm{R} 1\end{array}$ & $\begin{array}{c}\mathrm{M} / \mathrm{C}- \\
\mathrm{R} 2\end{array}$ & $\begin{array}{c}M / C- \\
\text { R3 }\end{array}$ & $\begin{array}{c}\text { Ap- } \\
\text { R }\end{array}$ & $3 \mathrm{Cb}$ & Marit & G27 & $17 C 7$ & $\mathrm{Ba} 142$ & $12 \mathrm{~A} 3$ & $8 C 8$ & G104 & Ver1 & Ver2 \\
\hline $\begin{array}{l}\text { Presence } \\
\text { of cagA } \\
\text { gene }\end{array}$ & + & - & - & + & + & + & + & - & + & - & + & + & + & + & + & + & - & + & + & - & + & + \\
\hline $\begin{array}{l}\text { Pathology } \\
\text { of } \\
\text { patients }\end{array}$ & $\mathrm{CGO}$ & $\mathrm{CGO}$ & $\mathrm{CGO}$ & GC & DU & $\mathrm{GC}$ & $\mathrm{CGO}$ & $\mathrm{CGO}$ & $\mathrm{CGO}$ & $\mathrm{CGO}$ & $\mathrm{CGO}$ & DU & GC & $\mathrm{CGO}$ & DU & GC & $\mathrm{CGO}$ & GC & GC & $\mathrm{CGO}$ & $\mathrm{CGO}$ & $\mathrm{CGO}$ \\
\hline $\begin{array}{l}\text { Primary } \\
\text { strain }\end{array}$ & Yes & Yes & Yes & Yes & Yes & Yes & Yes & Yes & No & No & No & No & Yes & No & Yes & Yes & Yes & Yes & Yes & Yes & No & No \\
\hline
\end{tabular}

* This is an isogenic $\operatorname{cagA}$ negative mutant of the wild strain 328 .

CGO: chronic gastritis only; DU: duodenal ulcer; GC: gastric carcinoma. 
Table 2 MBCs of polysorbate 80 , antibiotics and association of polysorbate 80 and antibiotics to the $H$. pylori strains tested; the values are expressed in $\mu \mathrm{g} / \mathrm{ml}$ and reported as mean and standard deviation in parentheses

\begin{tabular}{|c|c|c|c|c|c|c|c|c|c|c|c|c|c|c|c|c|c|c|c|c|c|c|}
\hline \multirow[t]{2}{*}{ Drugs } & \multicolumn{22}{|c|}{ Helicobacter pylori strains } \\
\hline & $\begin{array}{l}\text { CCUG } \\
17874\end{array}$ & G50 & G21 & $4 \mathrm{~Kb}$ & DiSim & $10 \mathrm{~K}$ & 328 & $328 \mathrm{Km}$ & M/C-R1 & $\mathrm{M} / \mathrm{C}-\mathrm{R} 2$ & $\mathrm{M} / \mathrm{C}-\mathrm{R3}$ & Ap-R & $3 \mathrm{Cb}$ & Mar-iot & G27 & $17 \mathrm{C7}$ & Ba 142 & $12 \mathrm{~A} 3$ & $8 C 8$ & G104 & Ver1 & Ver2 \\
\hline $\begin{array}{l}\text { Polysorbate } \\
80\end{array}$ & $\begin{array}{l}6.6 \\
(2.3)\end{array}$ & $16(0)$ & $8(0)$ & $\begin{array}{l}13.3 \\
(4.6)\end{array}$ & $16(0)$ & $32(0)$ & $32(0)$ & $\begin{array}{l}26.6 \\
(9.2)\end{array}$ & $\begin{array}{l}21.3 \\
(9.2)\end{array}$ & $32(0)$ & $16(0)$ & $13.3(4.6)$ & $16(0)$ & $16(0)$ & $8(0)$ & $16(0)$ & $8(0)$ & $2.6(1.1)$ & $\begin{array}{l}10.6 \\
(4.6)\end{array}$ & $8(0)$ & $6.6(2.3)$ & $16(0)$ \\
\hline Amoxicillin & $0.08(0)$ & $0.01(0)$ & $0.08(0)$ & $0.01(0)$ & $0.005(0)$ & $0.002(0)$ & $0.02(0)$ & $0.02(0)$ & $\begin{array}{l}0.005 \\
(0)\end{array}$ & $\begin{array}{l}0.07 \\
(.02)\end{array}$ & $0.01(0)$ & $0.005(0)$ & $0.01(0)$ & $\begin{array}{l}0.07 \\
(.02)\end{array}$ & $0.6(.1)$ & $0.1(.04)$ & $0.5(0)$ & $0.03(0)$ & $0.06(0)$ & $\begin{array}{l}0.05 \\
(.02)\end{array}$ & $0.04(0)$ & $0.08(0)$ \\
\hline Clarithromycin & $0.25(0)$ & $0.01(0)$ & $0.01(0)$ & $0.08(0)$ & $0.08(0)$ & $\begin{array}{l}0.11 \\
(.05)\end{array}$ & $0.2(0)$ & $0.02(0)$ & $320(0)$ & $\begin{array}{l}2500 \\
(0)\end{array}$ & $\begin{array}{l}0.03 \\
(.01)\end{array}$ & $0.04(0)$ & $0.04(0)$ & $32(0)$ & $\begin{array}{l}0.11 \\
(.05)\end{array}$ & $0.06(0)$ & $0.5(0)$ & $0.06(0)$ & $\begin{array}{l}0.05 \\
(.02)\end{array}$ & $\begin{array}{l}0.06 \\
(0)\end{array}$ & $32(0)$ & $64(0)$ \\
\hline Metronidazole & $32(0)$ & $0.4(0)$ & $2.6(.3)$ & $0.8(0)$ & $2.13(0.9)$ & $\begin{array}{l}20.8 \\
(7.2)\end{array}$ & $\begin{array}{l}21.3 \\
(9.2)\end{array}$ & $1.6(0)$ & $\begin{array}{l}26.6 \\
(9.2)\end{array}$ & $0.8(0)$ & $2.13(.9)$ & $0.8(0)$ & $0.67(.23)$ & $64(0)$ & $128(0)$ & $0.25(0)$ & $1.0(0)$ & $0.25(0)$ & $1.3(.5)$ & $\begin{array}{l}0.25 \\
(0)\end{array}$ & $128(0)$ & $\begin{array}{l}170.6 \\
(73.9)\end{array}$ \\
\hline Levofloxacin & $0.32(0)$ & $\begin{array}{l}0.27 \\
(.09)\end{array}$ & $0.32(0)$ & $0.16(0)$ & $0.16(0)$ & $0.32(0)$ & $\begin{array}{l}0.13 \\
(.05)\end{array}$ & $0.16(0)$ & $0.25(0)$ & $0.32(0)$ & $0.16(0)$ & $0.32(0)$ & $0.13(.05)$ & $0.32(0)$ & $0.16(0)$ & $0.25(0)$ & $\begin{array}{l}0.21 \\
(.07)\end{array}$ & $0.12(0)$ & $0.5(0)$ & $2(0)$ & $0.25(0)$ & $\begin{array}{l}0.21 \\
(.07)\end{array}$ \\
\hline Tetracycline & $2.0(0)$ & $0.25(0)$ & $\begin{array}{l}1.67 \\
(.58)\end{array}$ & $1.0(0)$ & $0.06(0)$ & $2.0(0)$ & $0.03(0)$ & $\begin{array}{l}0.04 \\
(.02)\end{array}$ & $0.06(0)$ & $0.06(0)$ & $0.25(0)$ & $0.25(0)$ & $0.05(.02)$ & $4(0)$ & $6.6(2.3)$ & $0.25(0)$ & $\begin{array}{l}0.67 \\
(.29)\end{array}$ & $0.5(0)$ & $0.5(0)$ & $2.0(0)$ & $0.32(0)$ & $\begin{array}{l}0.16 \\
(.13)\end{array}$ \\
\hline $\begin{array}{l}\text { Polysorbate } \\
\text { 80/ } \\
\text { Amoxicillin }\end{array}$ & $\begin{array}{l}4(0) / \\
0.08(0)\end{array}$ & $\begin{array}{l}6.6(2.3) / \\
0.01(0)\end{array}$ & $\begin{array}{l}3.1(1.1) / \\
0.08(0)\end{array}$ & $\begin{array}{l}4(0) / \\
0.01(0)\end{array}$ & $\begin{array}{l}4(0) / \\
0.005(0)\end{array}$ & $\begin{array}{l}3.1(1.1) / \\
0.002(0)\end{array}$ & $\begin{array}{l}4(0) / \\
0.02(0)\end{array}$ & $\begin{array}{l}6.6(2.3) / \\
0.01(0)\end{array}$ & $\begin{array}{l}21.3 \\
(9.2) / \\
.01\end{array}$ & $\begin{array}{l}16(0) / \\
0.02 \\
(.01)\end{array}$ & $\begin{array}{l}6.6(2.3) / \\
.01(0)\end{array}$ & $\begin{array}{l}4(0) / \\
0.01(0)\end{array}$ & $\begin{array}{l}4(0) / \\
0.01 \\
(0)\end{array}$ & $\begin{array}{c}4(0) / \\
0.04(0)\end{array}$ & $\begin{array}{c}4(0) / \\
0.02(0)\end{array}$ & $\begin{array}{l}3.1(1.1) / \\
0.04(0)\end{array}$ & $\begin{array}{l}3.1(1.1) / \\
0.3(.14)\end{array}$ & $\begin{array}{l}2.6(1.1) / \\
0.03(0)\end{array}$ & $\begin{array}{l}4(0) / \\
0.05 \\
(.02)\end{array}$ & $\begin{array}{l}4(0) / \\
0.04 \\
(.01)\end{array}$ & $\begin{array}{l}3.1(1.1) / \\
0.04(0)\end{array}$ & $\begin{array}{l}4(0) / \\
0.05 \\
(.02)\end{array}$ \\
\hline $\begin{array}{l}\text { Polysorbate } \\
80 / \\
\text { Clarithromycin }\end{array}$ & $\begin{array}{l}2(0) / \\
0.016 \\
(0)\end{array}$ & $\begin{array}{l}4(0) / \\
0.02 \\
(.01)\end{array}$ & $\begin{array}{l}3.1(1.1) / \\
0.11 \\
(.05)\end{array}$ & $\begin{array}{l}4(0) / \\
0.01(0)\end{array}$ & $\begin{array}{l}8(0) / \\
0.05(0)\end{array}$ & $\begin{array}{l}4(0) / \\
0.01(0)\end{array}$ & $\begin{array}{l}8(0) / \\
0.025 \\
(0)\end{array}$ & $\begin{array}{l}8(0) / \\
0.05(0)\end{array}$ & $\begin{array}{l}4(0) / 20 \\
(0)\end{array}$ & $\begin{array}{l}8(0) / \\
2.5(0)\end{array}$ & $\begin{array}{l}3.1(1.1) / \\
0.005(0)\end{array}$ & $\begin{array}{l}4(0) / \\
0.02(.01)\end{array}$ & $\begin{array}{c}4(0) / \\
0.01(0)\end{array}$ & $\begin{array}{c}3.1 \\
(1.1) / 8.0 \\
(0)\end{array}$ & $\begin{array}{c}3.1 \\
(1.1) / \\
0.05(0)\end{array}$ & $\begin{array}{c}4(0) / \\
0.01(0)\end{array}$ & $\begin{array}{c}2(0) / \\
0.016(0)\end{array}$ & $\begin{array}{l}2.6(1.1) / \\
0.02 \\
(.01)\end{array}$ & $\begin{array}{c}3.1 \\
(1.1) / \\
0.01(0)\end{array}$ & $\begin{array}{l}4(0) / \\
0.01 \\
(0)\end{array}$ & $\begin{array}{l}2.6(1.1) / \\
3.1(1.1)\end{array}$ & $\begin{array}{l}4(0) / \\
8(0)\end{array}$ \\
\hline $\begin{array}{l}\text { Polysorbate } \\
80 / \\
\text { Metronidazole }\end{array}$ & $\begin{array}{l}2(0) \\
/ 2(0)\end{array}$ & $\begin{array}{l}4(0) / \\
0.25(0)\end{array}$ & $\begin{array}{l}4(0) / \\
1(0)\end{array}$ & $\begin{array}{l}8(0) / \\
0.2(0)\end{array}$ & $\begin{array}{l}4(0) / \\
0.8(0)\end{array}$ & $\begin{array}{l}4(0) / \\
8(0)\end{array}$ & $\begin{array}{l}4(0) / \\
0.25(0)\end{array}$ & $\begin{array}{l}32(0) / \\
0.8(0)\end{array}$ & $\begin{array}{l}8(0) / \\
4(0)\end{array}$ & $\begin{array}{l}8(0) / \\
0.1(0)\end{array}$ & $\begin{array}{l}4(0) / \\
1(0)\end{array}$ & $\begin{array}{l}8(0) / \\
0.2(0)\end{array}$ & $\begin{array}{c}16(0) / \\
0.67(.23)\end{array}$ & $\begin{array}{l}16(0) / \\
16(0)\end{array}$ & $\begin{array}{l}4(0) / \\
106.6 \\
(37)\end{array}$ & $\begin{array}{l}8(0) / \\
0.16 \\
(.08)\end{array}$ & $\begin{array}{l}8(0) / \\
0.2(0)\end{array}$ & $\begin{array}{l}2.6(1.1) / \\
0.08(0)\end{array}$ & $\begin{array}{c}6.6 \\
(2.3) / \\
0.8(0)\end{array}$ & $\begin{array}{l}8(0) / \\
0.16 \\
(.08)\end{array}$ & $\begin{array}{c}6.6(2.3) / \\
64(0)\end{array}$ & $\begin{array}{l}4(0) / \\
106.6 \\
(37)\end{array}$ \\
\hline $\begin{array}{l}\text { Polysorbate } \\
80 / \\
\text { Levofloxacin }\end{array}$ & $\begin{array}{l}8(0) / \\
0.16(0)\end{array}$ & $\begin{array}{l}16(0) / \\
0.32(0)\end{array}$ & $\begin{array}{l}6.6(2.3) / \\
0.32(0)\end{array}$ & $\begin{array}{l}10.6 \\
(4.6) / 1 \\
(0.4)\end{array}$ & $\begin{array}{l}13.3 \\
(4.6) / \\
0.13(.46)\end{array}$ & $\begin{array}{l}8(0) / \\
0.31(0)\end{array}$ & $\begin{array}{l}32(0) / \\
0.16(0)\end{array}$ & $\begin{array}{l}16(0) / \\
1.6(0)\end{array}$ & $\begin{array}{l}32(0) / \\
0.25(0)\end{array}$ & $\begin{array}{l}32(0) / \\
0.32(0)\end{array}$ & $\begin{array}{l}16(0) / \\
0.16(0)\end{array}$ & $\begin{array}{l}13.3 \\
(4.6) / \\
0.27(.09)\end{array}$ & $\begin{array}{c}9.33 \\
(6.11) / \\
0.13(.05)\end{array}$ & $\begin{array}{l}8(0) / \\
0.27 \\
(.09)\end{array}$ & $\begin{array}{c}8(0) / \\
0.16(0)\end{array}$ & $\begin{array}{c}16(0) / \\
0.25(0)\end{array}$ & $\begin{array}{l}8(0) / \\
0.21 \\
(.07)\end{array}$ & $\begin{array}{c}2.6(1.1) / \\
0.12(0)\end{array}$ & $\begin{array}{l}8(0) / \\
0.42 \\
(.14)\end{array}$ & $\begin{array}{l}8(0) / \\
2(0)\end{array}$ & $\begin{array}{c}6.6(2.3) / \\
0.25(0)\end{array}$ & $\begin{array}{l}16(0) / \\
0.16 \\
(.13)\end{array}$ \\
\hline $\begin{array}{l}\text { Polysorbate } \\
80 / \\
\text { Tetracycline }\end{array}$ & $\begin{array}{l}8(0) / \\
2(0)\end{array}$ & $\begin{array}{l}13.3 \\
(4.6) / \\
0.25(0)\end{array}$ & $\begin{array}{l}8(0) / \\
2(0)\end{array}$ & $\begin{array}{l}8(0) / \\
0.67 \\
(.29)\end{array}$ & $\begin{array}{l}16(0) / \\
0.08 \\
(.03)\end{array}$ & $\begin{array}{l}16(0) / \\
2(0)\end{array}$ & $\begin{array}{l}32(0) / \\
0.03(0)\end{array}$ & $\begin{array}{l}16(0) / \\
0.04 \\
(.02)\end{array}$ & $\begin{array}{l}32(0) / \\
0.06(0)\end{array}$ & $\begin{array}{l}32(0) / \\
0.03(0)\end{array}$ & $\begin{array}{l}13.3 \\
(4.6) / \\
0.25(0)\end{array}$ & $\begin{array}{l}8(0) / \\
0.16(.08)\end{array}$ & $\begin{array}{c}13.3(4.6) / \\
0.042 \\
(.014)\end{array}$ & $\begin{array}{c}16(0) / 4 \\
(0)\end{array}$ & $\begin{array}{c}6.6 \\
(2.3) / \\
6.6(2.3)\end{array}$ & $\begin{array}{l}8(0) / \\
0.16 \\
(.08)\end{array}$ & $\begin{array}{c}8(0) / \\
067(.29)\end{array}$ & $\begin{array}{c}2.6(1.1) / \\
0.42 \\
(.14)\end{array}$ & $\begin{array}{l}8(0) / \\
0.5(0)\end{array}$ & $\begin{array}{c}6.6 \\
(2.3) / 2 \\
(0)\end{array}$ & $\begin{array}{c}6.6(2.3) / \\
0.16(0)\end{array}$ & $\begin{array}{l}8(0) / \\
0.16 \\
(.08)\end{array}$ \\
\hline
\end{tabular}


concentration at which $\geq 50 \%$ of strains were killed) was 16 (0). All strains were susceptible to amoxicillin $(<1.0 \mu \mathrm{g} / \mathrm{ml})$ and $\mathrm{MBCs}$ ranged from $0.002(0)$ to $0.6(0.1)$; the $\mathrm{MBC}_{50}$ was $0.03(0)$ (Table 2). Five secondary isolates (23.9\%), were resistant to clarithromycin (> $1.0 \mu \mathrm{g} / \mathrm{ml}$ ) (Table 2). Two strains presented a high level of resistance with $\mathrm{MBC}$ of 320 (0) and 2500 (0), while MBC of the other strains were 32 (0) for two strains and 64 (0) (Table 2). MBCs for the susceptible strains ranged from $0.01(0)$ to $0.5(0)$ (Table 2) and the $\mathrm{MBC}_{50}$ was 0.08 (0). Eight strains (36.3\%, four strains were secondary) were resistant to metronidazole (>4 $\mu \mathrm{g} / \mathrm{ml}$ ) (Table 2); MBCs for resistant strains were 20.8 (7.2), 21.3 (9.2), 26.6 (9.2), 32 (0), 64 (0), 128 (0) for two strains and 170.6 (73.9) (Table 2). All strains, excepted one primary strain, were susceptible to levofloxacin $(<2 \mu \mathrm{g} / \mathrm{ml})$ (Table 2); MBCs ranged from $0.12(0)$ to $0.5(0)$ and the $\mathrm{MBC}_{50}$ was 0.25 (0) (Table 2). Finally, one primary and one secondary strains $(9.0 \%)$ were resistant to tetracycline with MBC of 4 (0) and 6.6 (2.3); one strain was also resistant to metronidazole and clarithromycin, the other strain to metronidazole only. MBCs of tetracycline for the susceptible strains $(<4 \mu \mathrm{g} / \mathrm{ml})$ ranged from $0.03(0)$ to $2(0)$ and the $\mathrm{MBC}_{50}$ was $0.25(0)$.

\section{Determination of the chemosusceptibility of $\mathrm{H}$. pylori strains to polysorbate 80 used in association with clarithromycin or metronidazole}

The combination of polysorbate 80 with metronidazole increased the size of the growth inhibition halos (Figure 1); around the disk containing polysorbate 80 , a minimal halo of complete inhibition of growth, $\sim 1 \mathrm{~mm}$, can be seen. Subculture tests showed the presence of another halo of about $4 \mathrm{~mm}$ contains developed dead bacteria. The same effect was observed when clarithromycin was assayed

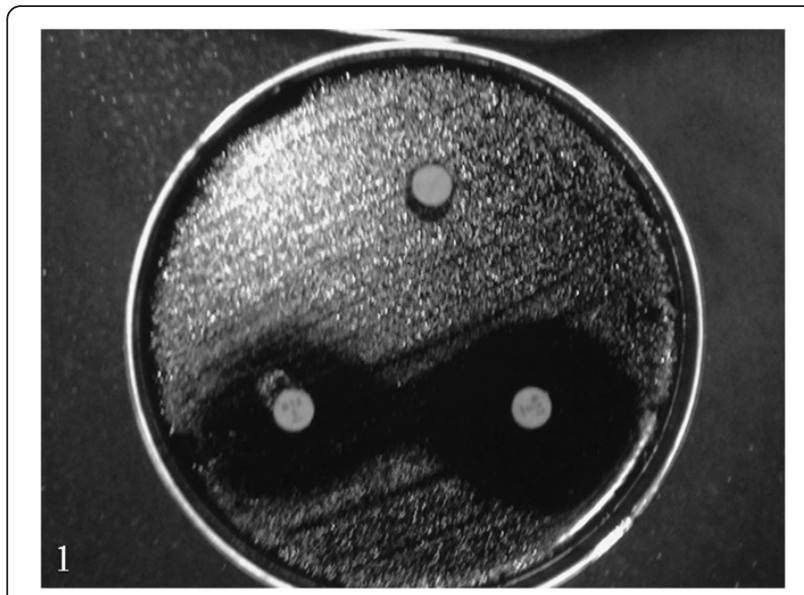

Figure 1 The combination of polysorbate 80 with metronidazole (disc on the right) increases the size of the growth inhibition halo; the disc on the left was charged with metronidazole alone and the disc at the top with polysorbate 80 alone. alone and with polysorbate 80 (data not shown). Halo sizes around discs charged with polysorbate 80 and amoxicillin, or levofloxacin, or tetracycline were not larger than those obtained with single antibiotics (data not shown). The synergistic effect of the association polysorbate 80 /clarithromycin and polysorbate 80 /metronidazole was confirmed by the broth dilution tests (Table 2). When used in association, the MBCs of polysorbate 80 decreased by 2-4 times and those of antibiotics by 2-16 times, compared to the respective MBCs of drugs used alone. The effect of the association of polysorbate 80 with amoxicillin, or levofloxacin, or tetracycline was negligible (Table 2).

TEM analysis of CCUG 17874 and C/M-R2 H. pylori strains treated with polysorbate 80 , alone and in association with clarithromycin and metronidazole

The ultrastructural characteristics of the two untreated strains appeared different from each other. CCUG $17874 \mathrm{H}$. pylori organisms showed homogeneous cytoplasm and rare detachment membrane/cytoplasm (Table 3, Figure 2A); 5\% of cells presented an altered profile. C/M-R2 organisms showed homogeneous cytoplasm and vesicles (Figure 2B). In both strains, flagella have been observed (Table 3 ).

To examine the ultrastructural characteristics of the organisms treated with the studied substances, the bacteria were incubated overnight with the single drugs and with antibiotics associated with polysorbate 80 at concentrations corresponding to the respective MBCs. In both strains treated with polysorbate 80 (Table 3), we observed swollen bacteria and alterations of the outer membrane (Figures 2C, 2D), particularly evident in CCUG $17874 \mathrm{H}$. pylori strain. The cytoplasm showed a typical granular texture; in both strains, we noted the presence of vesicles, which were more numerous in C/M-R2 strain.

The two strains challenged with clarithromycin showed different ultrastructural alterations. CCUG 17874 H. pylori strain (Figure 2E) was characterised by altered forms with typical "holes" in the cytoplasm and detachment of the inner membrane from the cytoplasm or cytoplasm retraction; flagella were observed, whereas vesicles were absent (Table 3). In C/M-R2 strain the morphology was conserved in about half of the analyzed bacteria (Figure 2F), whereas $\sim 40 \%$ of cells showed granular cytoplasm and $\sim 35 \%$ altered outer membrane. Flagella were observed and vesicles were present in C/M-R2 strain only (Table 3).

As far as the strains assayed with metronidazole are concerned, CCUG 17874 strain was characterised by organisms with severely altered shape and peculiar detachments between membrane and cytoplasm that often appeared fragmented (Figure 2G); flagella and vesicles were not observed in the sample (Table 3). C/M-R2 strain did not show any peculiar ultrastructural alterations after metronidazole treatment (Figure 2H). 
Table 3 Approximate percentages of organisms showing ultrastructural alterations observed in two $H$. pylori strains after treatment with polysorbate $\mathbf{8 0}$, clarithromycin, metronidazole, polysorbate $\mathbf{8 0 / c l a r i t h r o m y c i n ~ a n d ~ p o l y s o r b a t e ~}$ 80/metronidazole

\begin{tabular}{|c|c|c|c|c|c|c|c|c|c|c|c|c|}
\hline \multirow[t]{3}{*}{ Parameters } & \multirow{2}{*}{\multicolumn{2}{|c|}{ Controls }} & \multirow{2}{*}{\multicolumn{2}{|c|}{ Polysorbate 80}} & \multirow{2}{*}{\multicolumn{2}{|c|}{ Clarithromycin }} & \multirow{2}{*}{\multicolumn{2}{|c|}{ Metronidazole }} & \multirow{2}{*}{\multicolumn{2}{|c|}{$\begin{array}{c}\text { Polysorbate } 80 / \\
\text { Clarithromycin } \\
\end{array}$}} & \multirow{2}{*}{\multicolumn{2}{|c|}{$\begin{array}{c}\text { Polysorbate } 80 / \\
\text { Metronidazole }\end{array}$}} \\
\hline & & & & & & & & & & & & \\
\hline & $\begin{array}{l}\text { CCUG } \\
17874\end{array}$ & $\begin{array}{c}\mathrm{C} / \mathrm{M}- \\
\mathrm{R} 2\end{array}$ & $\begin{array}{l}\text { CCUG } \\
17874\end{array}$ & $\begin{array}{c}\mathrm{C} / \mathrm{M}- \\
\mathrm{R} 2\end{array}$ & $\begin{array}{l}\text { CCUG } \\
17874\end{array}$ & $\begin{array}{l}\mathrm{C} / \mathrm{M}- \\
\mathrm{R} 2\end{array}$ & $\begin{array}{l}\text { CCUG } \\
17874\end{array}$ & $\begin{array}{c}\mathrm{C} / \mathrm{M}- \\
\mathrm{R} 2\end{array}$ & $\begin{array}{l}\text { CCUG } \\
17874\end{array}$ & $\begin{array}{c}\mathrm{C} / \mathrm{M}- \\
\mathrm{R} 2\end{array}$ & $\begin{array}{l}\text { CCUG } \\
17874\end{array}$ & $\begin{array}{l}\mathrm{C} / \mathrm{M}- \\
\mathrm{R} 2\end{array}$ \\
\hline$\%$ Altered Shape & 5 & 3 & 90 & 60 & 85 & 50 & 85 & 5 & 100 & 95 & 85 & 80 \\
\hline \% Granular Cytoplasm & 1 & 3 & 90 & 70 & 10 & 40 & 5 & 5 & 75 & 60 & 70 & 65 \\
\hline$\%$ Altered outer membrane & 1 & 1 & 75 & 75 & 20 & 35 & 20 & 1 & 70 & 75 & 70 & 75 \\
\hline $\begin{array}{l}\% \text { Presence of "holes" in the } \\
\text { cytoplasm }\end{array}$ & 0 & 0 & 1 & 0 & 40 & 2 & 2 & 1 & 20 & 1 & 1 & 15 \\
\hline $\begin{array}{c}\text { \% Detachment membrane/ } \\
\text { cytoplasm }\end{array}$ & 3 & 1 & 10 & 2 & 30 & 2 & 60 & 2 & 25 & 2 & 50 & 10 \\
\hline$\%$ Presence of flagella & YES & YES & NO & YES & YES & YES & NO & YES & YES & YES & NO & NO \\
\hline$\%$ Presence of vesicles & - & + & ++ & ++++ & - & ++ & - & + & $+/-$ & ++++ & ++ & ++ \\
\hline
\end{tabular}

In the samples treated with both polysorbate 80 and clarithromycin, the shape was altered in both bacterial strains and the synergic effect of the two compounds was evident (Figures 2I, 2J). The examination of CCUG 17874 strain revealed swollen cells, granular cytoplasm and altered outer membrane, typical alterations induced by polysorbate 80 , together with detachment of the inner membrane from the cytoplasm and "holes" in the cytoplasm, typical effect of clarithromycin (Table 3). Flagella and rare vesicles were observed. C/M-R2 strain showed swollen bacteria with cytoplasm that gradually had lost its homogeneity; numerous vesicles and rare fragments of flagella were present (Table 3). The examination of CCUG 17874 strain treated with polysorbate 80 and metronidazole (Figure 2K) showed swollen bacteria with non-homogeneous cytoplasm, presence of vesicles (typical features of polysorbate 80 treatment) concomitant with peculiar detachments of the membrane from cytoplasm that often appeared fragmented (typical alterations caused by metronidazole). Vesicles were present, flagella were not observed (Table 3). C/M-R2 strain showed swollen bacteria with granular cytoplasm and the presence of vesicles (Figure 2L), all characteristics typical of polysorbate 80 treatment (Table 3); no flagella were found.

\section{Discussion}

Chemoresistances are the main cause of therapeutic failure of $H$. pylori infection [18]. The occurrence of acquired resistances in such species is very high, because of certain characteristics that make $H$. pylori hypermutable [19]. Mutation rates in $H$. pylori are in fact 10-700 fold higher than that observed in other species, for instance Escherichia coli; in addition, the mechanisms of acquired chemoresistance in $H$. pylori include its significant genetic competence (i.e. the ability to recombine exogenous DNA) [19]. Stress conditions, such as the antibiotic treatment and the exposure to the gastric acid, induce numerous events in this species, which may end up enhancing the frequency of chemoresistances: a) the transcription and translation of natural competence genes, which increase the frequency of transformation; b) the transcription of a lysozyme-like protein, which promotes DNA donation from the neighbouring cells; c) the stimulation of DNA uptake machinery, which increases the import of foreign DNA [20]. An additional source of genetic exchange is the transfer of genomic islands by conjugative mechanisms [21]. If we consider that the antibiotics utilizable in the treatment of $H$. pylori infection are limited and that it is mandatory to use them in combination of two or three at a time to be efficacious, the obvious conclusion is that in a few years physicians might lack effective antibiotics.

These observations prompted various researchers to investigate non-antibiotic compounds for their antimicrobial activity against $H$. pylori. Phytomedicine holds great promise for the treatment of $H$. pylori infection; however, it did not overcome the problem of resistance to the current antibiotics, nor has potentiated the antibiotic treatment [22]. The results of the present study showed that polysorbate 80 is bactericidal towards $H$. pylori with MBCs that could easily be achieved in the stomach. In addition, experiments in animals have established that polysorbate 80's toxic dosages are very high: the equivalent toxic dosage for human beings is > $350 \mathrm{~g}$ a day for three days [23]. The best demonstration that such substance is safe and well tolerated comes from the observation that it became part of most foods in Europe and America, where each person ingests about $100 \mathrm{mg}$ of polysorbate 80 in foods per day [24].

As polysorbate 80 is a detergent, it is likely that it exerts an antimicrobial activity against $H$. pylori by reacting with the bacterial outer membrane. Thus, in order to shed light 

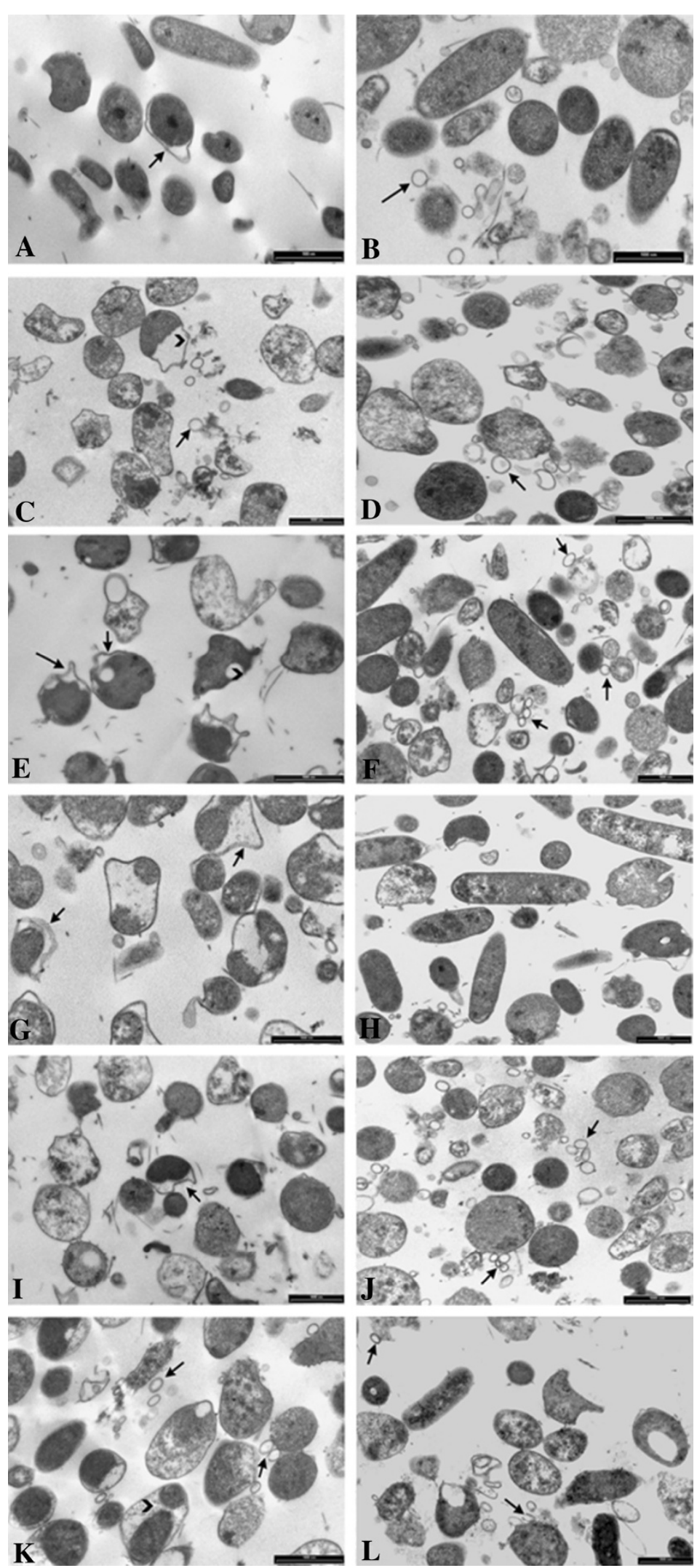

Figure 2 (See legend on next page.) 


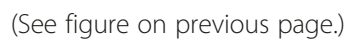

Figure 2 TEM micrographs of CCUG 17874 (A, C, E, G, I, K) and M/C-R2 (B, D, F, H, J, L) H. pylori strains. CCUG 17874 untreated bacteria (Figure 2A) show homogeneous cytoplasm and rare membrane/cytoplasm detachments (arrow). M/C-R2 untreated bacteria (Figure 2B) show homogeneous cytoplasm, flagella and vesicles (arrow). CCUG 17874 bacteria treated with polysorbate 80 (Figure 2C) are swollen and morphologically altered; cytoplasm is granular and detached from the inner membrane (arrow head); vesicles (arrow) are present. M/C-R2 bacteria treated with polysorbate 80 (Figure 2D) are swollen and morphologically altered; cytoplasm is not homogeneous and numerous vesicles are present (arrow). CCUG 17874 bacteria treated with clarithromycin (Figure 2E) show altered shape, typical "holes" in the cytoplasm (arrow head), membrane/cytoplasm detachment (arrows) and fragments of flagella. Some M/C-R2 organisms treated with clarithromycin (Figure 2F) have a conserved morphology, others show granular cytoplasm and altered membranes. Flagella and vesicles (arrows) are present. CCUG 17874 bacteria incubated with metronidazole (Figure $2 \mathrm{G}$ ) are severely altered and show detachment of cytoplasm, often fragmented, from inner membrane (arrows). M/C-R2 bacteria treated with metronidazole (Figure $2 \mathrm{H}$ ) are morphologically similar to control. CCUG 17874 treated with polysorbate 80 and clarithromycin (Figure 2l) displays alterations typical of organisms treated with the two substances used alone: swollen cells and detachment membrane/cytoplasm (arrow). M/C-R2 bacteria treated with polysorbate 80 and clarithromycin (Figure $2 \mathrm{~J}$ ) are mostly swollen, their cytoplasm is granular and numerous vesicles are present (arrows). CCUG 17874 strain treated with polysorbate 80 and metronidazole (Figure 2K) displays swollen bacteria, granular cytoplasm, presence of vesicles (arrows) and detachment of fragmented cytoplasm from the inner membrane (arrow head). M/C-R2 bacteria treated with polysorbate 80 and metronidazole (Figure $2 \mathrm{~L}$ ) are swollen; cytoplasm is granular and displays the presence of "holes". Vesicles are present (arrows). Bars 2A-L: $1000 \mathrm{~nm}$.

upon its mechanism of action, we examined by TEM strains exposed to polysorbate 80 , alone and associated with metronidazole and clarithromycin, the two antibiotics with which it showed a synergistic effect.

The observed morphological alterations in all samples treated with polysorbate 80 are conceivably caused by the detergent properties of this compound. Every time the bacteria have been treated with polysorbate 80 , typical and recurrent ultrastructural anomalies have been detected, namely alterations of the bacterial shape, swelling of the organisms, loss of the normal and homogeneous cytoplasmic structures, anomalies in the bacterial envelope especially in the outer membrane and the presence of numerous vesicles. In the CCUG 17874 strain the vesicles were detectable only after polysorbate 80 treatments, used alone and in combination with antibiotics. Different is the situation for the M/C-R2 strain, in which the vesicles were present in the control (untreated) samples, but they became more numerous in the treated specimens. The ability of some $H$. pylori strains to naturally produce vesicles is well known [25]; however, after treatment of this strain with polysorbate 80 , the number of vesicles definitely increased. The vesicles most likely originate from the outer membrane of bacteria: in the presence of detergents, the phospholipid bilayer is disrupted and micellae-like structures are produced. It is noteworthy that in both strains treated with polysorbate 80 we observed similar ultrastructural alterations, such as swelling of the organisms, alterations of the outer membrane and cytoplasm and presence of vesicles. A different behaviour of both strains was detected after treatment with antibiotics. Clarithromycin induced peculiar ultrastructural alterations in CCUG 17874 strain, namely typical "holes" in the cytoplasm, whereas in C/M-R2 strain we observed organisms with granular cytoplasm and altered envelopes. Similar modifications were described in strains treated with a different macrolide, erythromycin [26]. Metronidazole caused severe alterations in CCUG 17874 strain whereas it did not alter the normal morphology in the C/M-R2 strain, as also observed by Armstrong et al. [26].

In the specimens treated with antibiotics in association with polysorbate 80 , the bacteria showed a combination of ultrastructural anomalies typical of the organisms challenged separately with the antibiotics, but at concentrations reduced by approximately four-times.

The observation of a synergistic effect of polysorbate 80 associated with metronidazole and clarithromycin deserves some comments. We have observed a reduction of metronidazole's MBCs when the drug was associated with polysorbate 80 , independently of whether strains were metronidazole susceptible or resistant. It is likely that the mechanism of synergy consists in an increased influx or improved bioavailability of such chemotherapic, determined by the damage of the outer membrane exerted by polysorbate 80 (as shown by TEM). This interpretation is supported by the observation that resistance to metronidazole might be overcome with increased doses of drug [27].

Out of the eight metronidazole resistant strains used to evaluate the outcome of associations, in three cases, polysorbate tested with metronidazole reduced the MBCs of the chemoterapic to concentrations at which strains can be considered susceptible, i.e. $\leq 4 \mu \mathrm{g} / \mathrm{mL}$. The main mechanism of metronidazole resistance in $H$. pylori consists in mutations in $r d x A$ and $\operatorname{rrx} A$ genes, which encode an $\mathrm{NADPH}$ nitroreductase and an oxidoreductase, respectively [28]; the drug has to be reduced by bacterial reductive enzymes to exert its antimicrobial activity. Some researchers, however, claim that the first step to the development of metronidazole resistance consists in the overexpression of hefA gene, which encodes for an efflux pump [29]. Efflux pumps are very common amongst bacteria, including $H$. pylori, and protect them from the possible toxic effects of metabolite or antibiotic accumulation $[30,31]$. One component of a family of multidrug efflux transporters [32], widespread only among Gram-negative 
bacteria, is localised in the outer membranes [33]. Since it has been shown that the inactivation of any constituent of the efflux mechanism can abrogate the function of the entire group of efflux systems [29], we have speculated that the damage of the outer membrane exerted by polysorbate 80 could have caused the loss of such efflux transporter in our strains, thus impairing the mechanism of resistance. The strains still resistant to metronidazole even after treatment with polysorbate 80 could also have undergone a mutation of the reduction systems, i.e. it had a double mechanism of resistance.

The increased susceptibility to clarithromycin used in combination with polysorbate 80 could also be due to an augmented permeability of membranes exerted by the detergent. The main constituent of the outer membrane in Gram-negative bacteria is lipopolysaccharide (LPS); it coats the cell surface and works to exclude large hydrophobic compounds, such as antibiotics, from invading the cell. LPS has a significant role in membrane transport: the lipid compositions of LPS and the associated proteins have a strong impact on the sensitivity of bacteria to many types of antibiotics [34]. Unlike small hydrophilic antibiotics, large lipophilic agents, such as macrolides, have difficulty in diffusing through the LPS. Previous studies indicate that membrane permeabilizers, such as Tris/EDTA, polymyxin B etc., have the ability to increase the levels of antibiotic inflow [34] and consequently the sensitivity of Gram-negative bacteria to hydrophobic antibiotics, including macrolides [35,36]. In this study, two strains were highly resistant to clarithromycin, with MBCs of $320 \mu \mathrm{g} / \mathrm{mL}$ and $2500 \mu \mathrm{g} / \mathrm{mL}$. In the presence of polysorbate 80 , clarithromycin's MBCs decreased by 16 times and 1000 times, respectively, i.e. to $20 \mu \mathrm{g} / \mathrm{mL}$ and $2.5 \mu \mathrm{g} / \mathrm{mL}$, which still are in the range of resistant values (threshold $=1 \mu \mathrm{g} / \mathrm{mL}$ ). In these cases, we hypothesize the concomitance of two mechanisms of resistance. In a large number of bacterial species, in fact, the existence of drug-resistant strains is due to modifications in the lipid or protein composition of the outer membrane, which work in synergy with other resistance mechanisms [34]. Point mutations in 23S rRNA normally account for the development of resistance to clarithromycin in H. pylori and reduce the chances of eradication when the classical triple therapy is employed [37]. It is likely that in our strains the presence of an efflux apparatus cooperates with putative 23S rRNA mutations to make these two strains highly resistant to clarithromycin [38]. Polysorbate 80 conceivably increased their sensitivity by destroying the outer membrane; strains, however, were still resistant because of the existence of another putative mechanism, such as ribosome mutation.

A plausible explanation for the observation that the association of polysorbate 80 with amoxicillin, levofloxacin and tetracycline was not synergistic may consist in the sizes and hydrophilic nature of antimicrobials. Macromolecules such as clarithromycin, which hardly penetrate into bacteria using the lipid layer, exploit the alterations of the bacterial outer membranes to diffuse into microorganisms. Small hydrophilic antibiotics, such as $\beta$-lactams, tetracycline, fluoroquinolones etc., use porin channels to cross the outer membrane and diffuse very well [39]. For this reason, they do not take advantage by the disruption of membranes; thus their association with polysorbate 80 is indifferent.

\section{Conclusions}

In conclusion, polysorbate 80 shows a bactericidal activity against $H$. pylori and exerts a synergistic effect with some chemotherapics. We therefore propose such compound for the treatment of $H$. pylori infection in association with antibiotics.

\section{Methods}

\section{Determination of MBC}

The 22 strains used are listed in Table 1. The whole study was conducted following the approval of the local University Hospital Ethics Committee. All patients gave a written informed consent prior to inclusion of strains isolated from them in the study. Bacterial suspensions were stored in glycerol broth at $-80^{\circ} \mathrm{C}$ until the $\mathrm{MBC}$ determination was carried out. Suspensions were thawed and subcultured twice in selective Brucella agar plates (Pylori plates, BioMérieux, Italia S.p.A., Rome, Italy.) containing $10 \%$ foetal calf serum and $10 \mathrm{mg} / \mathrm{L}$ of each vancomycin, trimethoprim, and amphotericin $\mathrm{B}$ and $5 \mathrm{mg} / \mathrm{L}$ of cefsulodin. Plates were incubated in jars with a microaerobic environment generated using Campy Pak sleeves (Oxoid Ltd., Basingstoke, England).

Polysorbate 80 and antibiotics -amoxicillin, clarithromycin, metronidazole, tetracycline and levofloxacin(Sigma Aldrich-Milan, Italy) were dissolved in sterile water containing (when necessary) $4 \%$ of DMSO, sterilized by filtration and double diluted in Brucella broth containing $10 \%$ foetal calf serum, $10 \mathrm{mg} / \mathrm{L}$ of each vancomycin, trimethoprim, and amphotericin $\mathrm{B}$ and $5 \mathrm{mg} / \mathrm{L}$ of cefsulodin (to avoid contaminations). One microwell contained plain broth and was the control. Tests were carried out in triplicate in a final volume of $0.1 \mathrm{~mL}$, using Microtiter ${ }^{\circledR}$ plates. H. pylori suspensions were prepared starting from cultures on Brucella agar with $10 \%$ foetal calf serum incubated in a microaerobic environment for $48 \mathrm{~h}$. The bacterial suspensions were then added to each microwell at a final concentration of approximately $10^{6}$ colony-forming units per $\mathrm{mL}$. After $24 \mathrm{~h}$ of incubation under microaerobic conditions at $37^{\circ} \mathrm{C}, 3 \mu \mathrm{L}$ of broth from each dilution were deposited onto Brucella agar plates, which were incubated for 35 days in a microaerobic atmosphere at $37^{\circ} \mathrm{C}$. The lowest 
concentration in broth, for which the subculture on agar showed complete absence of growth, was considered the $\mathrm{MBC}$. Results are the average of three determinations.

\section{Determination of antimicrobial activity of polysorbate 80 associated with antibiotics}

Tests to evaluate the possible synergistic effect of polysorbate 80 associated with antibiotics were performed on all strains. Two methods have been used, the disc diffusion and the broth dilution techniques. Briefly, bloodagar plates were seeded using a swab with a suspension of the type strain CCUG 17874 or the strain C/M-R2, whose density corresponded to McFarland no. 4 opacity standard. After the surface was dried, three paper discs were deposited on each plate, one disc was charged with the antibiotic (amoxicillin $2 \mu \mathrm{g}$, clarithromycin $15 \mu \mathrm{g}$, metronidazole and levofloxacin $5 \mu \mathrm{g}$ each and tetracycline $10 \mu \mathrm{g})$, one with polysorbate $80(0.4 \mathrm{mg})$ and the third one with both drugs, polysorbate 80 and antibiotic, at the same concentration present in the discs charged with single antibiotics. After a 3-day incubation in microaerobic environment at $37^{\circ} \mathrm{C}$, plates were inspected and the halos of growth inhibition measured. The broth dilution test was carried out as follows: after the first drug was diluted, the second drug was added to each well of the first row containing different concentrations of the first compound; afterwards, the dilution of the second compound was carried out. Concurrently, we determined the MBC of the single substances. Tests were performed in triplicate.

\section{Ultrastructural analysis of $H$ pylori with transmission electron microscopy (TEM)}

For the ultrastructural analysis two strains of $H$. pylori were used: CCUG 17874 (metronidazole resistant type strain, isolated from a chronic gastritis case) and C/MR2 (clarithromycin resistant clinical strain isolated from a chronic gastritis case). These two strains were treated with: 1-polysorbate 80, 2-clarithromycin, 3metronidazole, 4- polysorbate 80 and clarithromycin, 5- polysorbate 80 and metronidazole. The other antibiotics were not tested because they did not exert any synergistic effect when examined in association with polysorbate 80 .

The bacterial suspensions, after overnight incubation with the drugs at the concentrations corresponding to the respective MBCs and MBCs of their associations, were washed in phosphate-buffered saline (PBS), fixed in cold Karnovsky fixative and maintained at $4^{\circ} \mathrm{C}$ for $2 \mathrm{~h}$. Fixed organisms were washed in $0.1 \mathrm{~mol} / \mathrm{L}$ cacodylate buffer ( $\mathrm{pH} 7.2)$ for $12 \mathrm{~h}$ at $4^{\circ} \mathrm{C}$ and postfixed in $1 \%$ buffered osmium tetroxide at $4^{\circ} \mathrm{C}$ for $1 \mathrm{~h}$. Then the samples were washed in $0.1 \mathrm{~mol} / \mathrm{L}$ cacodylate buffer $(\mathrm{pH} 7.2)$ for at least $2 \mathrm{~h}$ at $4^{\circ} \mathrm{C}$, dehydrated in a series of ethanol
(50\%, 75\%, 95\%, 100\%), exchanged through propylene oxide and embedded in Epon Araldite. Ultra-thin sections were obtained with a Supernova ultramicrotome (Reickert Jung, Vienna, Austria) with diamond knife, mounted on copper grids, stained with uranyl acetate and lead citrate and observed and photographed with a Philips EM208 TEM (Philips Scientifics, Eindhoven, The Netherlands).

A minimum of 500 bacteria per sample were analyzed and the anomalies related to the bacterial morphology (altered shape), the cytoplasm texture (granular cytoplasm, "holes" in the cytoplasm), the envelopes (altered envelopes, outer membrane detachment from the cell wall and cytoplasm detachment from the inner membrane), the presence of flagella and vesicles were quantified. The experiments were performed twice.

\section{Competing interests}

The authors declare that they have no competing interests.

This work was supported in part by Over Italia, S.r.l., Sora (Frosinone)

(Contract of research between Over and University of Siena N. 52514/III-17)

Italy. Over s.r.l. is the owner of the patent PCT/IT2011/000175.

\section{Authors' contribution}

NF: substantial contributions to conception and design, bacterial culture, susceptibility tests and manuscript writing. EM: substantial contributions to conception and design electron microscopy and manuscript writing. RM and GC substantial contributions to conception and design. GC: electron microscopy, revision of the manuscript. AS and AS: contribution of interpretation of the data. All the authors revised the manuscript and gave their final approval.

\section{Acknowledgements}

The authors wish to acknowledge Mr. Simone Pasquini, Novartis, Siena, Italy, for technical support in preparing the culture media and Dr. John Holton, University College London, medical School, London UK, for paper revision.

\section{Author details}

${ }^{1}$ Department of Internal Medicine, University of Siena, Siena, Italy. ${ }^{2}$ Centre for Biochemical and Clinical Study of Rheumatic Diseases, Siena, Italy. ${ }^{3}$ Qi s.r.l, Pomezia, Rome, Italy. ${ }^{4}$ Biotechnology Department, University of Siena, Siena, Italy. ${ }^{5}$ Department of Biomedical Sciences, Applied Biology Section,

University of Siena, Siena, Italy. ${ }^{6}$ Department of Clinical Medicine and Immunological Sciences, University of Siena, Siena, Italy.

Received: 11 May 2012 Accepted: 14 September 2012

Published: 22 September 2012

\section{References}

1. Telford JL, Covacci A, Rappuoli R, Ghiara P: Immunobiology of Helicobacter pylori infection. Curr Opin Immunol 1997, 9:498-503.

2. Walker MM, Crabtree JE: Helicobacter pylori infection and the pathogenesis of duodenal ulceration. Ann N Y Acad Sci 1998, 859:96-111.

3. Mégraud F: Basis for the management of drug-resistant Helicobacter pylori infection. Drugs 2004, 64:1893-1904.

4. Kusters JG, van Vliet AH, Kuipers EJ: Pathogenesis of Helicobacter pylori infection. Clin Microbiol Rev 2006, 19:449-490.

5. O'Connor A, Gisbert JP, McNamara D, O'Morain C: Treatment of Helicobacter pylori infection 2010. Helicobacter 2010, 15:46-52.

6. Gatta L, Vakil N, Leandro G, Di Mario F, Vaira D: Sequential therapy or triple therapy for Helicobacter pylori infection: systematic review and meta-analysis of randomized controlled trials in adults and children. Am J Gastroenterol 2009, 104:3069-3079.

7. Malfertheiner P, Bazzoli F, Delchier JC, Celiñski K, Giguère M, Rivière M, Mégraud F, Pylera Study Group: Helicobacter pylori eradication with a capsule containing bismuth subcitrate potassium, metronidazole, and 
tetracycline given with omeprazole versus clarithromycin-based triple therapy: a randomised, open-label, non-inferiority, phase 3 trial. Lancet 2011, 377:905-913.

8. Parente F, Cucino C, Bianchi PG: Treatment options for patients with Helicobacter pylori infection resistant to one or more eradication attempts. Dig Liver Dis 2003, 35:523-528.

9. De Francesco V, Giorgio F, Hassan C, Manes G, Vannella L, Panella C, lerard E, Zullo A: Worldwide $H$. pylori antibiotic resistance: a systematic review. J Gastrointestin Liver Dis 2010, 19:409-414.

10. Selgrad M, Malfertheiner P: Treatment of Helicobacter pylori. Curr Opin Gastroenterol 2011, 27:565-570.

11. Fischbach $L$, Evans EL: Meta-analysis: the effect of antibiotic resistance status on the efficacy of triple and quadruple first-line therapies for Helicobacter pylori. Aliment Pharmacol Ther 2007, 26:343-357.

12. Laine L, Fennerty MB, Osato M, Sugg J, Suchower L, Probst P, Levine JG: Esomeprazole-based Helicobacter pylori eradication therapy and the effect of antibiotic resistance: results of three US multicenter, double-blind trials. Am J Gastroenterol 2000, 95:3393-3398.

13. Treiber $G$, Malfertheiner $P$, Klotz U: Treatment and dosing of Helicobacter pylori infection: when pharmacology meets clinic. Expert Opin Pharmacother 2007, 8:329-350.

14. Vítor JMB, Vale FF: Alternative therapies for Helicobacter pylori: probiotics and phytomedicine. FEMS Immunol Med Microbiol 2011, 63:153-164.

15. Zhang H, Shen $Y$, Weng P, Zhao G, Feng F, Zheng X: Antimicrobial activity of a food-grade fully dilutable microemulsion against Escherichia coli and Staphylococcus aureus. Int J Food Microbiol 2009, 135:211-215.

16. Stoops JK, Arora R, Armitage L, Song L, Blackburn MR, Krueger GR, Risin SA: Certain surfactants show promise in the therapy of pulmonary tuberculosis. In Vivo 2010, 24:687-694.

17. Huesca M, Gold B, Sherman P, Lewin P, Lingwood C: Therapeutics used to alleviate peptic ulcers inhibit $H$. pylori receptor binding in vitro. Zentralbl Bakteriol 1993, 280:244-252.

18. Duck WM, Sobel J, Pruckler JM, Song Q, Swerdlow D, Friedman C, Sulka A, Swaminathan B, Taylor T, Hoekstra M, Griffin P, Smoot D, Peek R, Metz DC, Bloom PB, Goldschmidt S, Parsonnet J, Triadafilopoulos G, Perez-Perez Gl, Vakil N, Ernst P, Czinn S, Dunne D, Gold BD: Antimicrobial resistance incidence and risk factors among Helicobacter pylori -infected persons, United States. Emerg Infect Dis 2004, 10:1088-1094.

19. Björkholm B, Sjolund M, Falk PG, Berg OG, Engstrand L, Andersson DI: Mutation frequency and biological cost of antibiotic resistance in Helicobacter pylori. Proc Natl Acad Sci USA 2001, 98:14607-14612.

20. Dorer MS, Fero J, Salama NR: DNA damage triggers genetic exchange in Helicobacter pylori. PLoS Pathog 2010, 6:e1001026.

21. Fischer W, Windhager L, Rohrer S, Karnholz A, Hoffmann R, Zimmer R, Haas R: Strain-specific genes of Helicobacter pylori: genome evolution driven by a novel type IV secretion system and genomic island transfer. Nucleic Acids Res 2010, 38:6089-6101.

22. Ndip RN, Malange Tarkang AE, Mbullah SM, Luma HN, Malongue A, Ndip LM, Nyongbela K, Wirmum C, Efange SM: In vitro anti-Helicobacter pylori activity of extracts of selected medicinal plants from North West Cameroon. J Ethnopharmacol 2007, 114:452-457.

23. Williams J, Odum J, Lewis RW, Brady AM: The oral administration of polysorbate 80 to the immature female rat does not increase uterine weight. Toxicol Lett 1997, 91:19-24.

24. Ema M, Hara H, Matsumoto M, Hirata-Koizumi M, Hirose A, Kamata E: Evaluation of developmental neurotoxicity of polysorbate 80 in rats. Reprod Toxicol 2008, 25:89-99.

25. Parker $\mathrm{H}$, Keenan I: Composition and function of Helicobacter pylori outer membrane vesicles. Microbes Infect 2012, 14:9-16

26. Armstrong JA, Wee SH, Goodwin CS, Wilson DH: Response of Campylobacter pyloridis to antibiotics, bismuth and an acid-reducing agent in vitro-an ultrastructural study. J Med Microbiol 1987, 24:343-350.

27. Chey WD, Wong BC: American College of Gastroenterology guideline on the management of Helicobacter pylori infection. Am J Gastroenterol 2007, 102:1808-1825.

28. Marais A, Bilardi C, Cantet F, Mendz GL, Mégraud F: Characterization of the genes $r d x A$ and frxA involved in metronidazole resistance in Helicobacter pylori. Res Microbiol 2003, 154:137-144.

29. Tsugawa H, Suzuki H, Muraoka H, Ikeda F, Hirata K, Matsuzaki J, Saito Y, Hibi T: Enhanced bacterial efflux system is the first step to the development of metronidazole resistance in Helicobacter pylori. Biochem Biophys Res Commun 2011, 404:656-660.

30. van Amsterdam K, Bart A, van der Ende A: A Helicobacter pylori TolC efflux pump confers resistance to metronidazole. Antimicrob Agents Chemother 2005, 49:1477-1482.

31. Liu ZQ, Zheng PY, Yang PC: Efflux pump gene hefA of Helicobacter pylori plays an important role in multidrug resistance. World J Gastroenterol 2008, 14:5217-5222.

32. Paulsen IT, Chen J, Nelson KE, Saier MH Jr: Comparative genomics of microbial drug efflux systems. J Mol Microbiol Biotechnol 2001, 3:145-150.

33. Johnson JM, Church GM: Alignment and structure prediction of divergent protein families: periplasmic and outer membrane proteins of bacterial efflux pumps. J Mol Biol 1999, 287:695-715.

34. Delcour AH: Outer membrane permeability and antibiotic resistance. Biochim Biophys Acta 2009, 1794:808-816.

35. Vaara M: Agents that increase the permeability of the outer membrane. Microbiol Rev 1992, 56:395-411.

36. Savage PB: Multidrug-resistant bacteria: overcoming antibiotic permeability barriers of gram-negative bacteria. Ann Med 2001, 33:167-171.

37. Mahachai V, Sirimontaporn N, Tumwasorn S, Thong-Ngam D, Vilaichone RK: Sequential therapy in clarithromycin-sensitive and -resistant Helicobacter pylori based on polymerase chain reaction molecular test. J Gastroenterol Hepatol 2011, 26:825-828.

38. Bina JE, Alm RA, Uria-Nickelsen M, Thomas SR, Trust TJ, Hancock RE: Helicobacter pylori uptake and efflux: basis for intrinsic susceptibility to antibiotics in vitro. Antimicrob Agents Chemother 2000, 44:248-254.

39. Nikaido H: Molecular basis of bacterial outer membrane permeability revisited. Microbiol Mol Biol Rev 2003, 67:593-656.

doi:10.1186/1471-2180-12-217

Cite this article as: Figura et al:: Polysorbate 80 and Helicobacter pylori: a

microbiological and ultrastructural study. BMC Microbiology 2012 12:217.

\section{Submit your next manuscript to BioMed Central and take full advantage of:}

- Convenient online submission

- Thorough peer review

- No space constraints or color figure charges

- Immediate publication on acceptance

- Inclusion in PubMed, CAS, Scopus and Google Scholar

- Research which is freely available for redistribution 